\title{
E-Commerce Transaction in Hello Gold Investment: Islamic Investment Review
}

\author{
Raudzatul Jannah Binti Ezahar ${ }^{1}$, Mohd Sollehudin Shuib ${ }^{2 *}$, Ahmad Khilmy Abdul Rahim ${ }^{3}$ \\ ${ }^{1} \mathrm{PhD}$ Candidate, Islamic Business School, Universiti Utara Malaysia, MALAYSIA \\ 2,3Senior Lecturer, Islamic Business School, Universiti Utara Malaysia, MALAYSIA \\ *E-mail for correspondence: sollehudin@uum.edu.my
}

https://doi.org/10.18034/abr.v10i1.464

\begin{abstract}
With advancing the digital platform, many investment plans were introduced to share the benefits and potential assets invested. This paper aims to seek to understand the e-commerce of gold investment transactions from the context of Shariah. The methodology adopted was interview and document research from the qualitative study. Review of existing literature sheds light on some conditions that must be adhered to in e-commerce gold investment are the four pillars of Islamic contracts consist of contracting parties, the price, offer, and acceptance, and subject matter. Gold investment also has its own standard criteria and regulations that must be fulfilled according to Shariah where the item gold has considered as ribawi item. The finding shows that Hello Gold launched the first online gold platform e-commerce through a new mobile application Smart Saver Plan as an automated 12-months savings plan that helps customers have a saving gold monthly with little effort. The features of e-commerce mobile applications are equipped with easy steps of gold purchasing which contain detailed registration, price, features of the gold specification, and method payment system. Term and condition also adhered to gain the consent of customer engagement in the transaction. Hello Gold is a recognized Shariah-compliant whereby it complies with BNM guidelines. The appraisal of these criteria and features justified the validity of Hello Gold Smart Saver Plan from Shariah review perspectives. The ecommerce of mobile application also meets the Shariah ruling transaction which in turn enhance the level of online trust among Muslim users.
\end{abstract}

Key words: E-Commerce, Gold Investment, Islamic Investment

\section{INTRODUCTION}

In an increasingly digital world, people experiencing evolution of a new form investment and newer demand into more sophisticated and electronic form. The proliferation of business digitalization, e-commerce, and $\mathrm{m}$-commerce are some of the new evolving economic business expansion world nowadays. The system developed has affected varies of investment plans and strategies and lead towards revolutionary change within the Islamic finance and investment community.

One of the main areas that is significantly affected by the internet is the way people make transactions, business and trade in new and competitive environments (Zainul et al., 2004). In this article, the study will emphasize into seeking the understanding of e-commerce gold investment transaction specifically using e-commerce channel by using mobile application platform as the tool marketing in business transactions at HelloGold.

Of all the investment, gold is one of the most popular as an investment. There are various alternatives available for investment in gold through options (Nordin et al., 2018). Gold investment nowadays is not limited to conventional way by buying and keeping the gold physical, it has been transformed and expanded as a new form investment alternative such as physical gold-backed exchange traded funds (ETFs) (World Gold Council, 2017). In this kind of investment, the buyer of the gold does not need to risky by holding and keeping the gold himself (Mas'ad et al., 2018). However, from an Islamic perspective, there are several studies on issues of e-commerce gold investment transactions. The use of information and communication technology for online commercial transactions were seen 
to pose some Shariah issues (Muhammad et al., 2013a) when the scheme still practicing through conventional system which is the system is based on riba' (usury). This kind of gold investment scheme is automatically rejected and prohibited under Shariah regulation because this kind of scheme is not Shariah compliant and did not comply with the halal principle (Mas'ad et al., 2018). Nordin et al., (2018) reported that there are gold investment products, techniques and investment plans are not Shariah compliant.

The increasing of so many gold investment companies and banking institution which offered gold investment scheme and differ from one to another also rise into this question and concerns of Muslim faced today. For this reasons, before the investor or customer would like to enter in the gold investment, they should have some checking the products are comply with the Shariah rulings (Razimi et al., 2017). The author also discussed the issues on the investors' concern on elements gharar (uncertainty) in the gold transaction and the permissibility of the products based on the Islamic law. Gharar may exist when the investors cannot withdraw physical gold from their accounts which it raise the question on the status of the gold, whether or not it really exists in the bank's safekeeping (Razimi et al., 2017).

Despite many studies have examined issues related to gold investments from the Islamic perspective, yet none is found to empirically review the every single processes of e-commerce transaction by using platform mobile application in the light of Islamic law contract. To address this gap, this study discusses the Shariah principles and essential requirements of a contract and conduct a case study on HelloGold product transaction to investigate the Shariah compliant on its e-commerce transaction through mobile application. The scope of transaction including the method of purchase and payment system, subject matter of gold and price, contracting parties and offer and acceptance. The paper is organized as follows. The researcher will briefly discuss the legality of e-commerce from Islamic review perspective in the next section and review the literature of Islamic gold investment in section 3. Methodology and data are provided in section 4 . Section 5 presents and discusses the results and section 6 concludes the study.

\section{LITERATURE REVIEW}

\section{Legality of E-Commerce from an Islamic Review Perspective}

Ribadu and Rahman (2017) addressed Shariah accords ecommerce similar inference as for the traditional commerce. It involves the conformity to the principle of Islamic law of contract form (offer and acceptance), contracting parties (buyer and seller) and the subject matter (object and price) and to be devoid of any fundamentally prohibited element of riba (usury), gharar (uncertainty), haram (forbidden), and maysir (gambling).

Transaction in the e-commerce needs to be studied in Islamic law to provide a legal basis for the transaction as now many internet and banking fraud to get-rich-quick schemes on the rise. Many discussions need to be discussed regarding e-commerce, starting from transactions, payment systems, producer rights, consumer rights and the law of buying and selling ecommerce itself (Sholikhin and Amijaya, 2019).

E-Commerce refers to any form of business transaction executed using information and communication technology (ICT) (Muhammad et al., 2013b). Turban, King and Viehland (2004) define e-commerce as the process of buying, selling and transferring or exchanging products, service and/or information via computer network, including the Internet. According to Mokhtar et al. (2013) e-commerce transaction is a commercial transaction through electronic media which also covers all commercial transactions through electronic media such as facsimile, telex, Electronic Data Interchange and telephone.

Payment processing method or electronic payment system is important in e-commerce transaction or online transaction. According to Sumanjeet (2009) broadly electronic payment systems can be classified into four categories, Online Credit Card Payment System, Online Electronic Cash System, Electronic Cheque System and Smart Cards based Electronic Payment System.

Prior research conducted by Muhammad et al. (2013a) stated e-commerce transaction must confirm to the requirements and principles of Islamic law of contract which mainly aims at protecting interests and eliminating harms of parties involved in a transaction. The author also highlighted every e-commerce transaction must be free from fundamental prohibited elements such as usury (riba), uncertainty (gharar) and gambling (maysir). It is supported with Zainul et al. (2004) concluded certain condition that must be observed to ensure the legality of e-commerce in Islam including the clarity in the communication and the product offered, specify the prices, the mode of the delivery and the mode of the payment must be specified clearly. Second, both contracting parties must receive the message in order to achieve conformity in the agreement (concluding the contract). Third, there must be continuity in the communication, whether in the transmission of message or in consulting between one another via e-mail.

Muhammad et al. (2013b) study on e-commerce transaction in the context of Islamic law mentioned that for the contract to be considered valid, either in physical or virtual setting, it must fulfilled some requirements stipulated by the Shariah. 
Therefore, from the prior research, researcher may conclude that e-commerce transaction can be performed in any electronic medium platform including mobile and telephone which have similar to traditional way of buying and selling concepts which must take priority to the all pillars of Islamic contracts. E-commerce also must take into consider the connecting between buyer and seller in virtual, clearly specifying the subject matter and the price, and the continuity of communication between contracting parties are important to ensure the valid transaction in ecommerce. It is important to validate e-commerce system accordance with Islamic treaty law which requires the absence of usury, gharar, illicit objects and gambling to be permissible for Muslims (Mokhtar et al., 2013).

\section{Islamic Gold Investment}

However, from the perspective of Islamic Fiqh and the Islamic economic system, trading gold has a specific significance. This significance arises from the specific principles provided for gold and silver as Thaman (real money) in Shari'ah. The original sources of Shari'ah, the Holy Quran and Sunnah, contain numerous cautions on the use and hoarding of gold from a moral and ethical perspective. These include several prohibitive uses, as well as general guiding principles against the hoarding of gold and silver.

According to Majid et al., (2003) for gold account (which is refer to gold investment account) to be Sharia compliant, it must meet several criteria. First, the gold account must apply Bai' as-Sarf, in this case, that is, it refers to the exchange of money with gold on the spot basis (Al-Zuhayli, 2003). Under this contract, investor buys gold at the selling price that determined by the bank. Second, Qardh al-Hassan which refers to benevolent loan or beneficial loan, gratuitous loan, interest-free loan, beautiful loan, whereby the bank as a borrower is only required to return the commodity or the same principal sum borrowed (Haron and Azmi, 2009). Under this contract, the gold bought by investor will be deposited into a gold account with the bank as the debtor (Muqtaridh) and the investor as the creditor (Muqridh). The customer is guaranteed for the quantity of gold that deposited with the bank. These criteria make the gold account free from usury $\left(r i b a^{\prime}\right)$.

By having the physical gold as the subject matter in the contract of sale between the creditor and debtor make the contract valid and free from the element of uncertainty (gharar) which is strictly prohibited in Islam. Uncertainty may exist when the investor cannot withdraw physical gold from their accounts, which raise the question on the status of the gold, whether or not it really exists in the bank's custody (Ghazali et al., 2015).

Besides, the opening of such investment account becomes unlawful and void since the bank is selling something which is not in its rightful possession and usury occurs since there is no element of Taqabud fil-Majlis, that is, offer and acceptance during the same event. The transaction also becomes unlawful and void if the gold cannot be delivered immediately to the purchaser upon opening of the gold investment account.

Majid et al., (2003) added gold investment transactions are categorized as permissible (mubah) and valid when the two conditions are met, that is, when the bank rightfully owns the gold at the point of sale and the bank issues a proof of purchase in the form of physical gold or certificate to the customer and thus immediately gives the customer the rights to manage. The certificate functions like a debit card or cheque, which represents money that exists. The issuance of certificate, as a token to signify sales and account opening, is valid and permissible in the eyes of Islam. It is taken as a nonphysical delivery (al-Qabdhu al-Ma'nawi).

E-commerce environment can be largely found in the economic today. However, it scarcely looks at the issue from the Islamic perspective. There is a growing concern and need for Sharia compliance e-commerce to ensure that Sharia principles are adhered and user's desirable characteristics are provided (Ribadu and Rahman (2017). As religion is one of the aim objective in conducting the ecommerce, Muslim users therefore pertinent to explore how e-commerce be transacted from the perspective of Islamic law of contract when especially e-commerce associated to item ribawi, gold investment.

(If) gold sold with gold, silver with silver, wheat with wheat, sya'ir (types of wheat) with sya'ir, dates with dates, and salt with salt, the value (weight and value) must at par and pay cash on the spot. Whoever put addition or ask for addition, the have practiced Riba'. Whoever take the addition (from the origin value) and who paid for the addition both of them commiting sin.

(Imam Muslim, n.d)

Although there are still lack of research on e-commerce of gold investment previously, it denotes the same connotation with that of e-commerce buying and selling in Islam as take considering the all four pillars of Islamic contracts contracting parties, the price, offer and acceptance, subject matter of gold and gold standard criteria and regulations. Therefore, fulfilling all Shariah obligations would surely bring the trust to the Muslims in carry out e-commerce gold transaction comply with Shariah.

\section{Methodology}

The research design used in this study is a case study whereby researcher want to have in depth understanding in the process in a natural setting occurred (Creswell and Creswell, 2018). The method used in this study is primary, qualitative. This paper adopts the qualitative research method, relating to the growing issues of gold investment in Malaysia. Data sources include interviews, texts, and documents (i.e. archival research), specifically from the Central Bank of Malaysia (BNM), National Fatwa 
Council Malaysia, gold miners, gold manufacturer companies, bank product disclosure sheet, newspaper articles, magazines, goldsmiths and author's analysis. The technique used in this study is purposive sampling and data was analyzed by using content analysis and inductive analysis.

\section{Result AND Discussions}

\section{Gold Investment Product}

There is unanimous agreement among the participating scholars/experts on the need to absolutely ensure Sharia compliance of e-commerce systems (Ribadu and Rahman (2017).

Table 1: Gold Investment Product

\begin{tabular}{|l|l|}
\hline Features & Description \\
\hline Product & Smart Saver Plan \\
Category of Gold & Gold Account \\
Purity & Gold Purity: 99.99\% \\
Denomination & $1 \mathrm{~g}, 5 \mathrm{~g}, 10 \mathrm{~g}, 20 \mathrm{~g}$ \\
Initial Purchase & RM 30 and Hello Gold Buy RM1 as \\
& the lowest price every working day, \\
Operating Hours & $\begin{array}{l}\text { Buy and sell 23 Hours a day, 7 } \\
\text { days a week }\end{array}$ \\
Gold Authenticity & LBMA \\
\hline
\end{tabular}

Table 1 shows the features and product description of HelloGold investment product Smart Saver Plan. Smart Saver is a one of HelloGold plan to allow people to buy 99.99\% investment grade gold via their smart phone. This Hello Gold application who has started since February 2017 introduced on Google Play on IOS version is a new plan of HelloGold product which is an automated 12 month savings plan that helps customer save monthly with little effort. It is set monthly recurring savings deposit starting from RM 30 (subscription) and HelloGold will buy gold at the lowest price as RM 1 every working day and customer may be able check gold saving growth anytime through a mobile. Hello Gold offer buying from minimum $1 \mathrm{~g}, 5 \mathrm{~g}, 10 \mathrm{~g}, 20 \mathrm{~g}$ respectively within operating hours 23 hours a day and 7days a week. There is no cancellation fee and hidden cost.

The gold is resourced from an International gold refiner called Produits Artistiques Metaux Precieux (PAMP), which is a part of the London Bullion Market Association (LBMA) and insured by the worldwide renowned insurance underwriter Chubb International.

Hello gold is a non-principal guaranteed product, noninterest bearing account and it is not insured by Perbadanan Insurans Deposit Malaysia (PIDM). The net return on a Hello Gold account relates directly to the value of the gold held in the customer account. The returns on gold are uncertain and there is a risk or earning no returns and/or the possibility of incurring losses.
Hello Gold had been awarded as Most Innovative Islamic Retail Product 2017, Prominent in Wealth, Asset \& Investment Management 2018, Best Islamic Wealth Management Fintech Company 2018, Most Outstanding Islamic Fintech Company 2019 and Most Innovative Islamic Retail Product \& Fastest Growing Islamic Wealth Management Fintech Company 2019. Hello Gold also has been recognized Shariah-Compliant ethical Islamic financing company that complies with BNM Guidelines, Anti Money Laundering, Anti- Terrorism Financing and Proceeds of Unlawful Activities Act 2001, Financial Services Act 2013, Personal Data Protection Acts 2010.

\section{The Overview of Hello Gold Practice in E- COMmerce}

\section{Method of Purchase}

HelloGold launched first online gold platform to enable customer open a HelloGold account via the HelloGold Mobile App through smartphone. To be entitle to make a purchase, customer are required to download the application HelloGold from the Google Play and create an account at HelloGold by click registration and verify details by reading term and conditions before agree to proceed. Secondly, customers are need to tap on "Buy Gold" once they have landed on the dashboard after logging in. Enter the amount of gold they would like to buy. The essential features of HelloGold Smart Saver Plan includes buy allocated gold from as low as RM1 and sell the gold from any amount, automated savings with Smart Saver. Each sales and purchase expressed in RM is quoted in the HelloGold app and gold sale based on HelloGold prevailing gold buying price quoted in RM per gram and cash top-up or withdrawal through in-app bank transfer. Customer may select payment method ranging from cash balance, online banking, Boost. Once payment is successful, customer gold is instantly vaulted. What customer may have to do is fund monthly goal and the apps will automatically purchase gold for customer at the lowest gold price every weekday through the month. At the end of the 12 month period, customer may cash out their gold savings, claim the physical gold or continue grow their savings. Hello Gold charged annual administrative fee $2 \%$ per annum of the value gold held accrued on a daily basis and charged on a monthly basis.

\section{Method of Payment}

There are several of payment method can be performed for e-commerce. HelloGold however, enable customer to opt for other alternative which serve customer payment selection through Hello Gold account by way of transfers to, or from, a personal bank account, in customer own name which have linked to customer HelloGold Account; or transfers from customer Boost e-Wallet account linked to customer HelloGold Account or physical withdrawals of gold. For the validity of e-commerce, it is crucial for the accomplishment of online transactions from the Shariah 
viewpoint must be avoiding payment mode that involves the element of riba (usury). Islamic banking institutions have issued free interest saving account bank which underlying structures such as al-wadiah and it is Islamic payment system as Shariah compliant and applied in most of Islamic banking institutions. While, such payments which be facilitated through mobile e-wallet, Boost eWallet does not link to a bank account nor is it provided by a banking entity. It acts exactly like a physical wallet only and it exists electronically in the phone. Users need to top up their e-wallets by transferring money into these wallets before they are able to use them for any transactions. The money deposited in these wallets is put in a trust account where the presumed Shariah contract is al-wadiah where the keeper is not liable for compensation unless the object is broken or damaged because of his negligence (Zulkefli et al., 2019).

Therefore, researcher is more inclined to refer to the concept Boost e-wallet under concept of al-wadiah as per the reason mentioned above, and to consider them Shariah Compliant. However, in the case of gold transaction, postponement of payment is not allowed between seller and buyer because installment purchases in gold item are riba (usury) not acceptable and prohibited in Islam (Syed Alwi et al., 2013).

\section{Transfer Ownership}

The customer is required to acknowledge the receipt of the physical gold in person. By holding an account with HelloGold, customer are entrusting with the security of their gold. Bullion Star International as gold provider in Singapore will send a bar list showing what they hold in the vault for Hello Gold. These bar lists indicate all the gold that HelloGold hold on behalf of their customers and are publish daily on their websites. The lists bar contain customer serial number with bar type, weight, purity gold and vault location. Thus by publish customer lists and the amount of gold showing that it was secured and keep confidential as it's numbered. Hence, HelloGold's customer are not facing the issues of delay right possession customer as they will be able to check the totals and cross check the custody list totals directly to the bar lists.

This kind of way has avoid from gharar both parties; after customer buy a certain amount of physical gold, the customer may have a rights to withdraw the physical gold at any time as he able to do so because of the existence of the physical gold. Thus, by having the physical gold as the subject matter in the contract of sale between customer and HelloGold has made a contract valid and free from the element of gharar (uncertainty) which is prohibited in Islam (Syed Alwi et al., 2013).

It is pertinent to the National Fatwa Council Malaysia in their 96th conference on 13 -15 October 2011, in the case of gold transaction there are four conditions must be followed. First the subject matter must exist, wholly owned by the seller who can deliver to the purchaser within the uruf (custom) period. Next, the subject matter must be known its physical, weight and originality, third the value of the gold must be made know and agreed by both parties' seller and buyer during aqad (contract). Lastly, the contract must be executed based on mutual consent.

\section{Withdrawals/ Mode of Delivery}

If HelloGold's customer want to withdraw physical gold from the Smart Saver plan HelloGold, they may be able to do so as the customer have been given a serial number as the evidence right of tasarruf (managing) which specify to a quantity of gold purchased. Customers may requests for the redemption of physical gold from HelloGold through the HelloGold mobile apps. Each withdrawal of physical gold shall be subject to a minimum quantity of 1 gram and in multiples of 1 gram or such other minimum quantity as may be determined by HelloGold from time to time, subject to the payment of the prevailing fees, taxes and charges (inclusive of insurance and transport charges) for the delivery of the physical gold to the customer. The gold may come in PAMP Suisse gold either come in wafers or bars, depending on sizes. Basically the withdrawal process are require the customer to tap "Redeem" in the HelloGold apps and contacts HelloGold Customer Support team to place delivery request and customer will receive email notification of confirmation in regard gold shipment. HelloGold Bulllion provider uses a recognized courier service to deliver customers' gold according to customers' address logged in HelloGold's database. Upon delivery customer are required to present their My Kad/Valid Passport to ensure HelloGold account holder, personally receives the gold. In the case of this situation, HelloGold are not facing the issue of delaying delivery gold as the customer had been given the right of possession upon the payment in the transaction. Hence, it is permitted according to Islamic practice and Shariah.

\section{Closure of Account}

The customer is entitled to close the HelloGold account by selling all the gold therein to Hello Gold at the buying price as shall be quoted by HeloGold at the time of such sale and all proceeds of sale there from shall be paid to the customer in RM by crediting the customer's bank account. Additionally, HelloGold has the discretion to consider any HelloGold account closed if it appears in HelloGold's record that the HelloGold has a zero or nil balance for an extended period of time, upon with the withdrawal of all the gold and cash available in the HelloGold accounts by operation of law.

\section{The Shariah Complance E-commerce of Hello GOLD INVESTMENT}

\section{Contracting Parties}

In order to ensure the Islamic validity of a transaction conducted via e-commerce HelloGold, researcher has follow the pillars of Islamic contract as comparing the 
Shariah Compliance the e-commerce of HelloGold Investment transaction. In contracting parties both customer as a buyer and HelloGold as a seller must have the legal capacity (ahliyyah) to be eligible to enter into a contractual relationship. This is also important requirements to perform the gold transaction as item ribawi. HelloGold addressed the customer must be a citizen or permanent of Malaysia eighteen years of age or above and have a valid Malaysian identification card. However, when the customer want to engage into a transaction, details of account number of payment need to supplied accordingly as for payment processing. Thus, the ability to possess the payment is used as a proof for the customer's eligibility to conclude the transaction (Muhammad et al., 2013a). To added validity of ecommerce in Islam, two contracting parties who connected together via computer or any electronic device, first they should be clarity in the communication. Second, both contracting parties must receive the message in order to achieve conformity in the agreement (including the contract) and third, there must be continuity in the communication whether in the transmission of message or in consulting between one another via e-mail (Zainul et al., 2004). In this case of situation, HelloGold served communications between customer and HelloGold through by mail or by telephone, fax, online or by other electronic means from time to time. This such manner will have same legal effects as in traditional written form. All telephone calls and electronic communications be recorded and kept as a record.

\section{Subject Matter (Object and Pricing)}

The second pillar of Islamic contract is the existing of a subject matter. The subject matter in the case of HelloGold is refer to an existing of gold and features and pricing (Muhammad et al., 2013b). Product descriptions and information should also be clearly explained in order to prevent uncertainty (gharar) and ignorance. Ribadu and Rahman (2017) mention subject matter is the object and price of a sale contract which must be fulfilled to achieve Shariah compliance in e-commerce systems. In this case, HelloGold describes gold quality, purity, and auditing clearly expressing through HalloGold term and condition $(T \& C)$ and product disclosure on the apps. In this term and condition, the information like storage, insurance and fees are clearly precise in agreement for customer reference. While price of each denomination grams of gold are display everyday based on HelloGold's prevailing gold price quoted in RM per gram. Hello Gold, therefore, fulfills the Shariah requirement to provide sufficient information about a product gold being transacted in order to avoid any excessive gharar and ignorance.

\section{Offer and Acceptance}

Sighah (offer and acceptance) a term used by the fuqaha' (Muslim jurists) to refer to the formal exchange which takes place between the contractual parties indicating their willingness to enter into the contractual agreement and therefore constitutes the contract itself (islamicbanker.com). It indicates the pleasure of both parties to execute sale and purchase contract and can be carried out through verbal and written forms. In HelloGold, the offer are occur when the customer shows his interest in trading by clicking on the advertised item on a seller's website and then proceeds to checkout basket after knowing the specifications and the price. So, the offer occurs when the seller asks confirmation, such as "do you agree?" Al-Zahrani (2009) acceptance are consider whenever customer are click agree on term and condition apply before proceed to next transaction. Amboala et al. (2015) similarly stated the merchant who propose (offer) their product or contract to the customer (second party) who later accept it and make a payment via online are considered as communicating parties and bounded. Based on Shariah, this contract in e-commerce is legitimate because both parties expressing their wills through words (act) and clear to both parties without coercion (Zainul et al, 2004).

\section{CONCLUSION}

Unanimous agreement among the participating scholars and expert on the need to absolutely ensure Sharia compliance of e-commerce system (Ribadu and Rahman (2017). It is very needed and important to ensure that ecommerce systems and practice are ensuring Shariah compliant.

In this paper, we have analyzed the investment transaction of HelloGold e-commerce by using the platform mobile application from the context of Shariah. It is including the assessment of e-commerce application features built -in as lead consumer engagement into transaction business to consumer B2C (Business to Consumer). Findings show that HelloGold had start up their online gold platform namely Smart Saver to be able customer buy investment gold simple and affordable for everyone to buy, sell and save as low as RM 1 with fineness $99.99 \%$ investment grade gold via their smart phone. The legality of this e-commerce system through mobile application can be seen into their processing transactions such as method of purchase, payment systems and mode of delivery gold practice. The clarity of communication and the continuity between contracting parties HelloGold were occurred through by mail or by telephone, fax, online or by other electronic means from time to time which this manner have same legal effects as in traditional written form. Based on this, researcher make inclusion HelloGold Smart Saver have met the Shariah stipulation requirement based on their fulfilling of pillars Islamic contracts and gold standard criteria.

Conclusion can be made that this study is subject to certain limitations, first, futures study could be implemented from different sampling method to gather different view of 
understanding and findings. Next, our sample research was limited to one company HelloGold only. Samples from other company might show different results.

Moreover, there is significant knowledge gap discussing the transaction of gold investment towards mobile application usage in e-commerce. Despite growing interest from academic research, Muslim engagement in a mobile environment specifically with regard mobile application is, to the best of our knowledge, not explored. We aim to identify features of mobile application that are significant for Muslims engage as for the investment as it meet an essential requirements for Sharia compliant ecommerce specifically in Business to Consumer (B2C) setting (Ribadu and Rahman, 2019).

\section{REFERENCES}

Al Zahrani, S. A. (2009). Professional preference and decision making with a sample of professional college students In Jeddah, published Master's thesis in Psychology (Professional Educational Guidance), Faculty of Education Department of Psychology, Umm Al Qura University.

Al-Zuhayli, W. (2003), Islamic Jurisprudence and Its Proofs, Dar al-Fikr, 33.

Amboala, T., Mokhtar, A. H. A., Muhammad, M. Z., bin Noordin, M. F., \& Othman, R. (2015). Development method for shariah compliant e-commerce payment processing. International Journal of Computer Theory and Engineering, 7(5), 408-415.

Creswell, J.W. and Creswell, J.D. (2018). Research design: qualitative, quantitative, and mixed methods approaches, Thousand Oaks, California: SAGE Publications, Inc., Fifth edition

Ghazali, M. F., Lean, H. H., \& Bahari, Z. (2015). Sharia compliant gold investment in Malaysia: Hedge or safe haven?. PacificBasin Finance Journal, 34, 192-204.

Haron, S. and Azmi, W.N.W. (2009) Islamic Finance and Banking System Philosophies, Principles and Practices, McGraw-Hill Education

Imam Muslim. Abū al-Husayn 'Asākir ad-Dīn Muslim ibn alHajjāj ibn Muslim ibn Ward ibn Kawshādh al-Qushayrī anNaysābūrī or Muslim Nayshāpūrī, commonly known as Imam Muslim, Islamic scholar, particularly known as a muhaddith. His hadith collection, known as Sahih Muslim, is one of the six major hadith collections in Sunni Islam and is regarded as one of the two most authentic (sahih) collections, alongside Sahih al-Bukhari.

Majid, A. M. Nor, N.G. and Said, F.F. (2003) Efficiency of Islamic banks in Malaysia, Paper presented to the Fifth International Conference on Islamic Economics and Banking, Bahrain, October, 7-9.

Mas'ad, A. M., Rozali, M. E. A., Ismail, W. A. F. W., \& Johari, F. (2018). Gold Investment Practices in Malaysia: A Shariah
Review. Journal of Fatwa Management and Research, 13(1), 215-231. Retrieved from http://jfatwa.usim.edu.my/index.php/jfatwa/article/view/184

Mokhtar, A.H.A.; Amboala, T.; Muhammad, M.Z. and EAlam, M.S. (2013). "Bai as-salam and e-commerce: A comparative analysis from Shariah perspectives," in Proc. the 2nd Applied International Business Conference, vol. 7, p. 8.

Muhammad, M., Muhammad, M.R. \& Khalil, K.M. (2013a). Towards shari'ah compliant ecommercetransactions: A review of Amazon.com. Middle-East Journal ofScientific Research, 15(9), 1229-1236.

Muhammad, M., Muhammad, M.R., Suhaimi, M.A., Hussin, H., Razi, M.J.M. \& Abdullah, K. (2013b). Building trust in ecommerce from Islamic perspective: A literaturereview. American Academic and Scholarly Research Journal, 5(5), $161-168$

Nordin, N., Aziz, M. I., Embong, R., Daud, N., \& Aziz, S. A. (2018). Shariah Compliant Gold Investment: An Understanding among Academicians in Terengganu, Malaysia. International Journal of Academic Research in Business and Social Sciences, 8(10), 226-235.

Razimi, M.S.A.; Romle, A.R. and Azizan, K.A. (2017). An Understanding of Shariah Issues on Gold Investment: A Review, Asian Journal of Business Management Studies 8 (1): 09-12.

Ribadu, M.B., \& Rahman, W.N.W.A. (2017). E-Commerce Quality Evaluation Metrics: A Sharia Compliance Approach. Journal of Telecommunication, Electronic and Computer Engineering (JTEC), 9(3-5), 101-110.

Ribadu, M.B., \& Rahman, W.N.W.A. (2019). An integrated approach towards Sharia compliance E-commerce trust. Applied computing and informatics, 15(1), 1-6.

Sholikhin, M. Y., \& Amijaya, R. N. F. (2019). E-Commerce Based on the Law of Buying and Selling in Islam. KnE Social Sciences, 1360-1370.

Sumanjeet, S. (2009). Emergence of payment systems in the age of electronic commerce: The state of art. Global Journal of International Business Research, 2(2).

Syed Alwi, S. F., Suhaimi, M., \& Mohamed Kamil, M. M. (2013). Gold investment account in Kuwait finance house (M) Berhad and Maybank Berhad. Journal of al-Thaqafah, 3(1).

The gold market in 2017, 13 January, 2017, GOLDHUB, https://www.gold.org/goldhub/research/gold-market-2017

Zainul, N., Osman, F., \& Mazlan, S. H. (2004). E-Commerce from an Islamicperspective. Electronic Commerce Research and Applications, 3(3), 280-293. https:/ / doi.org/10.1016/j.elerap.2004.01.002

Zulkefli, A., Rusmadi, H., \& Aziz, A. A. (2019). Application of EWallet: A Preliminary Analysis from the Shariah Perspective. International Journal of Fiqh and Usul al-Fiqh Studies (IJFUS), 3(2), 98-105.

$--0--$ 
Online Archive: https://abc.us.org/ojs/index.php/abr/issue/archive 